\title{
Temperature and UV light affect the activity of marine cell-free enzymes
}

\author{
Blair Thomson ${ }^{1}$, Christopher David Hepburn ${ }^{1}$, Miles Lamare ${ }^{1}$, and Federico Baltar ${ }^{1,2}$ \\ ${ }^{1}$ Department of Marine Science, University of Otago, Dunedin, New Zealand \\ ${ }^{2}$ NIWA/University of Otago Research Centre for Oceanography, Dunedin, New Zealand \\ Correspondence to: Federico Baltar (federico.baltar@otago.ac.nz)
}

Received: 1 February 2017 - Discussion started: 7 February 2017

Revised: 30 June 2017 - Accepted: 7 August 2017 - Published: 13 September 2017

\begin{abstract}
Microbial extracellular enzymatic activity (EEA) is the rate-limiting step in the degradation of organic matter in the oceans. These extracellular enzymes exist in two forms: cell-bound, which are attached to the microbial cell wall, and cell-free, which are completely free of the cell. Contrary to previous understanding, cell-free extracellular enzymes make up a substantial proportion of the total marine EEA. Little is known about these abundant cell-free enzymes, including what factors control their activity once they are away from their sites (cells). Experiments were run to assess how cell-free enzymes (excluding microbes) respond to ultraviolet radiation (UVR) and temperature manipulations, previously suggested as potential control factors for these enzymes. The experiments were done with New Zealand coastal waters and the enzymes studied were alkaline phosphatase (APase), $\beta$-glucosidase, (BGase), and leucine aminopeptidase (LAPase). Environmentally relevant UVR (i.e. in situ UVR levels measured at our site) reduced cell-free enzyme activities by up to $87 \%$ when compared to controls, likely a consequence of photodegradation. This effect of UVR on cell-free enzymes differed depending on the UVR fraction. Ambient levels of UV radiation were shown to reduce the activity of cell-free enzymes for the first time. Elevated temperatures $\left(15^{\circ} \mathrm{C}\right)$ increased the activity of cell-free enzymes by up to $53 \%$ when compared to controls $\left(10^{\circ} \mathrm{C}\right)$, likely by enhancing the catalytic activity of the enzymes. Our results suggest the importance of both UVR and temperature as control mechanisms for cell-free enzymes. Given the projected warming ocean environment and the variable UVR light regime, it is possible that there could be major changes in the cell-free EEA and in the enzymes contribution to organic matter remineralization in the future.
\end{abstract}

\section{Introduction}

Heterotrophic microbes are ubiquitous in the marine environment, recycling most of the organic matter available in the oceans. The discovery of the microbial loop made clear that heterotrophic microbes are one of the most important nutrient vectors in marine food webs (Azam et al., 1983; Azam and Cho, 1987). According to the size-reactivity model, microbes selectively prefer high-molecular-weight dissolved organic matter (HMWDOM) due to its superior nutritional value (Amon and Benner, 1996; Benner and Amon, 2015). The main obstacle for the use of HMWDOM by microbes is that these compounds are generally too large to be transported across microbial cell membranes. Enzymatic hydrolysis outside of the cell is required to break HMWDOM down to smaller size fractions ( $<600 \mathrm{Da})$ before uptake can occur (Weiss et al., 1991). Thus, microbial extracellular enzymatic activity (EEA) is the process that initiates the microbial loop (Arnosti, 2011; Hoppe et al., 2002) and is recognized as the rate-limiting step in the degradation of organic matter in the oceans (Hoppe, 1991). This key role has led to extracellular enzymes being referred to as "gatekeepers of the carbon cycle" (Arnosti, 2011).

There are two forms of EEA: cell-bound, which are attached to the outside of the microbial cell wall or reside in the periplasmic space, and cell-free, which are completely free of the cell and are suspended in the water column. Cell-free enzymes can come from a variety of sources in the marine environment including the sloppy grazing behaviour of protists (Bochdansky et al., 1995; Hoppe, 1991), microbial starvation (Chroist, 1991), the lysis of cells by viruses (Kamer and Rassoulzadegan, 1995), and the direct release by mi- 
crobes in response to the detection of appropriate substrates (Alderkamp et al., 2007). Up until recently, research on extracellular enzymes has been mostly on cell-bound enzymes, as they were considered to be the only abundant form (Hoppe, 1983; Hoppe et al., 2002). This led to a view that cell-bound extracellular enzymes were the only form of ecological significance (Chróst and Rai, 1993; Rego et al., 1985). However, studies have now shown that the second form, cell-free extracellular enzymes, can make up a substantial proportion of the total extracellular enzyme pool (Baltar et al., 2010, 2013, 2016; Allison et al., 2012; Duhamel et al., 2010; Kamer and Rassoulzadegan, 1995; Li et al., 1998). This has been a major conceptual shift for research in marine enzymatic activity, generating new research questions about what controls cellfree enzymes in the marine environment and how they function (Arnosti, 2011; Arnosti et al., 2014; Baltar et al., 2010, 2016).

One of the many consequences of this discovery is that cell-free enzymes can be decoupled temporally and/or spatially from the microbial community that produces them (Arnosti, 2011; Baltar et al., 2010, 2016), since cell-free enzymes have long residence times after they are released, lasting up to several weeks (Baltar et al., 2013; Steen and Arnosti, 2011). The activity of cell-free enzymes away from their sites (cells) can condition macromolecular dissolved organic compounds (DOCs) and organic surfaces for subsequent microbial growth. This action at a distance complicates discerning links between producing microbes and their enzymes expression, as cell-free enzymes have the potential to contribute to the availability of nutrients at a great distance from the releasing cell (Arnosti, 2011; Baltar et al., 2010, 2016). It has been suggested that the history of the water mass may be more informative in understanding current cell-free enzyme activities than the history of in situ microbial communities present at the time of sampling (Baltar et al., 2010, 2013, 2016; Kamer and Rassoulzadegan, 1995; Arnosti, 2011).

There are only a limited number of published investigations into the dynamics of cell-free enzymes (Baltar et al., 2010, 2013, 2016; Kim et al., 2007; Steen and Arnosti, 2011; Li et al., 1998; Kamer and Rassoulzadegan, 1995; Duhamel et al., 2010). These papers provide good evidence of the importance of cell-free enzymes in the marine environment, but the controls for cell-free enzymes (once separated from the microbial cell) are poorly understood (Arnosti, 2011). Steen and Arnosti (2011) tested the effect of ultraviolet radiation (UVR) on cell-free enzymes directly, finding a reduction in cell-free enzyme activity only at artificially high UVR doses (i.e. UV-B intensities 5-10 times higher than in situ), with natural illumination showing no significant effects of photodegradation. One recent study by Baltar et al. (2016) in the Baltic Sea revealed strong correlations between seasonal temperature change and the proportion of cell-free to total EEA, suggesting seawater temperature and/or solar radiation as the most obvious abiotic mechanisms for the control of cell-free enzymatic activity. However, that was a field study of coastal waters, which includes the whole microbial community and many potential interactions and effects that can co-occur (e.g. production/consumption of free enzymes by microbes and variation in substrate concentration). Thus, to better understand the factors affecting marine free EEA we need to test the effect of environmental factors on free EEA under controlled conditions.

Here we isolated the free extracellular enzymes from a coastal site and specifically studied the effects of temperature and UVR on the activity of three cell-free extracellular enzyme groups: (i) alkaline phosphatase (APase), an enzyme used to acquire phosphorus from organic molecules; (ii) $\beta$ glucosidase (BGase), a glycolytic enzyme that targets carbohydrates groups; and (iii) leucine aminopeptidase (LAPase), an enzyme associated with the degradation of proteins. UVR treatments were hypothesized to reduce the activity of cellfree enzymes when compared to dark controls. Photodegradation with "high UVR dose" treatments (including the entire UV-B spectrum, 280 to $320 \mathrm{~nm}$ ) were hypothesized to have a stronger degradative effect on cell-free enzymes than "low UVR dose" treatments (only including a fraction of the UV-B spectrum, 280 to $305 \mathrm{~nm}$ ). This was based on the reported effects of UV-B on microbes and their metabolic rates including the total EEA (Herndl et al., 1993; Santos et al., 2012; Müller-Niklas et al., 1995; Demers, 2001). Compared to ambient temperatures $\left(10^{\circ} \mathrm{C}\right)$, cell-free enzymes exposed to high temperatures $\left(15^{\circ} \mathrm{C}\right)$ were hypothesized to be more active and vice versa, due to the general relationship between temperature and catalytic activity in enzymes (Daniel and Danson, 2010, 2013). Experiments carried out here are the first to directly test temperature effects on cell-free enzymes alone, and to directly test the effect of UVR on cell-free enzymes in the Southern Hemisphere and under in situ measured environmentally relevant UV irradiances.

\section{Materials and methods}

\subsection{Study site, sampling, and experiment preparation}

The experiments were conducted at the University of Otago's Portobello Marine Laboratory, situated on the Otago Harbour, Dunedin, New Zealand $\left(45.8281^{\circ} \mathrm{S}, 170.6399^{\circ} \mathrm{E}\right)$. Otago Harbour is a tidal inlet which has an area of 46 $\mathrm{km}^{2}$, consisting of two basins and with extensive sediment flats (Grove and Probert, 1999; Heath, 1975). The laboratory is based on the outer Otago Harbour, which has waters similar in composition to coastal seawater, owing to the short residence times for its waters exchanging with the open sea (Rainer, 1981; Grove and Probert, 1999). Samples were taken from the second metre of the water column off the marine laboratory's wharf that extends into a deep tidal channel. Prior to use, all sampling and laboratory equipment used were decontaminated using triplicate rinses 
of $18 \mathrm{M} \Omega \times \mathrm{cm}$ high-purity (Milli- $\mathrm{Q}^{\mathrm{TM}}$ ) water before and after soaking in $10 \%$ hydrochloric acid for more than $6 \mathrm{~h}$ and oven-dried at $60^{\circ} \mathrm{C}$. To separate the cell-free extracellular enzymes from the total extracellular enzyme pool and the microbial community, samples were triple filtered through low-protein-binding $0.22 \mu \mathrm{m}$ Acrodisc filters following published methods (Kim et al., 2007; Baltar et al., 2010). Then, $50 \mathrm{~mL}$ glass vials were filled with the $0.22 \mu \mathrm{m}$ filtered seawater for use in experiments. Bacterial abundance was determined after both experiments by preserving samples in glutaraldehyde and processing them using SYBR Green nucleic acid stain with a BD Accuri C6 flow cytometer (BD Biosciences, USA). This was done to ensure that no significant bacterial growth occurred after filtering or during incubation. Bacterial abundance was reduced to less than $1 \%$ of the prefiltered total and remained so during the $36 \mathrm{~h}$ incubations.

\subsection{UVR experiments}

To determine in situ UV irradiance and environmentally appropriate treatments for experiments, the attenuation of UVR was measured through the upper $2 \mathrm{~m}$ of the water column on site using a LI-COR LI1800UW spectroradiometer (LI-COR Biosciences, USA). The spectroradiometer was factory calibrated using NIST traceable standards. Once this was determined, artificial lighting was installed in a temperaturecontrolled room and set to the ambient seawater temperature of $10^{\circ} \mathrm{C}$. The lighting consisted of two FS20 UVR lamps (General Electric, Schenectady, NY, USA) and a full spectrum Vita-Lite 72 lamp (Duro Test, Philadelphia, PA, USA), suspended above the samples. These lights were height-adjusted to yield an irradiance of $3.03 \mathrm{~W} \mathrm{~m}^{-2} \mathrm{~s}^{-1}$, approximating UV irradiances measured in the field at $2 \mathrm{~m}$ depth $\left(3.5 \mathrm{~W} \mathrm{~m}^{-2} \mathrm{~s}^{-1}\right)$. Schott WG and GG long-pass filters $(15 \times 15 \mathrm{~cm})$ with nominal cutoffs $(50 \%$ transmission) in the UV-B ( 280 and $305 \mathrm{~nm}$ ) were placed above the filtered cell-free enzyme seawater samples contained in glass vials, with either the high dose $\left(<280 \mathrm{~nm}, 3.03 \mathrm{~W} \mathrm{~m}^{-2} \mathrm{~s}^{-1}\right.$, $130.8 \mathrm{~kJ})$ or the low dose $\left(<305 \mathrm{~nm}, 0.42 \mathrm{~W} \mathrm{~m}^{-2}, 18.1 \mathrm{~kJ}\right)$ of UVR. All light was blocked except that which passed directly through the long-pass filters onto the open glass vials to avoid any effect of the glass on the UVR dose. Controls were kept without light by wrapping the glass vials containing the filtered cell-free enzyme seawater samples in several layers of aluminium foil and were placed in the same temperature-controlled room. Readings of enzyme activity rates were taken from three replicates of each treatment at 12 and $36 \mathrm{~h}$ treatment time. UVR was not applied directly to the plate incubations as this can affect the fluorogenic substrate analogues used in the assays. Temperature inside the vials was also monitored to ascertain that the samples were constantly kept at the desired temperature.

\subsection{Temperature experiments}

For the temperature experiments we utilised a large graded heat block system (see Lamare et al., 2014, for design specifications). This heat block allowed for up to 15 replicate samples to be exposed to constant temperature treatments over time. The heat blocks were tested five times a day for 3 days in advance with blank samples to ensure the heat blocks were calibrated accurately; the variation in temperature was within $0.5^{\circ} \mathrm{C}$ of the target temperatures (i.e. 5,10 , and $15^{\circ} \mathrm{C}$ ) in all measurements. These temperatures were selected because 5 to $15^{\circ} \mathrm{C}$ is the annual range of temperature in the sampling site, and $10^{\circ} \mathrm{C}$ was the in situ temperature at the time of sampling (unpublished data). All treatments were kept in the dark by wrapping the glass vials containing the filtered cell-free enzyme seawater samples in several layers of aluminium foil. Readings of enzyme activity rates were taken of three replicates of each treatment at $6,12,24$, and $36 \mathrm{~h}$. When incubating these samples, each was put into a separate incubator, which was set to the respective treatment temperature so as to avoid confounding the temperature treatments.

\subsection{Extracellular enzymatic activity (EEA) assays}

We used the method for assessing EEA rates based on the hydrolysis of fluorogenic substrate analogues developed by Hoppe (1983). The fluorogenic substrates 4-methylcoumarinyl-7-amide (MCA)-L-leucine-7-amido4-methylcoumarin, 4-methylumbelliferyl (MUF)- $\beta$-Dglucoside, and MUF-phosphate were used to assess the leucine aminopeptidase, $\beta$-glucosidase, and alkaline phosphatase activities, respectively. Substrate concentrations of $100 \mu \mathrm{M}$ were used for each enzyme based on pre-established kinetics tested in the lab. Although differences in UVR or temperature might affect the kinetic parameters, we decided to use the same concentration for all the enzymes (which was saturating at the in situ conditions) to allow for a better comparison and reduce confounding factors. The 96-well Falcon microplates were filled with six replicates of each of the three fluorogenic substrates $(10 \mu \mathrm{L})$ and seawater $(290 \mu \mathrm{L})$ to make up $300 \mu \mathrm{L}$ reactions. Plates were read in a Spectramax M2 spectrofluorometer (Molecular Devices, USA), with excitation and emission wavelengths of 365 and $445 \mathrm{~nm}$, both before and after $3 \mathrm{~h}$ incubations. All incubations were performed in the dark with UVR incubations set to the in situ seawater temperature, and temperature incubations set to each respective treatment temperature. Six samples without substrate addition served as blanks in each plate to determine the background fluorescence of the samples, which were used to correct the activity rates in the plate readings before and after incubation. 


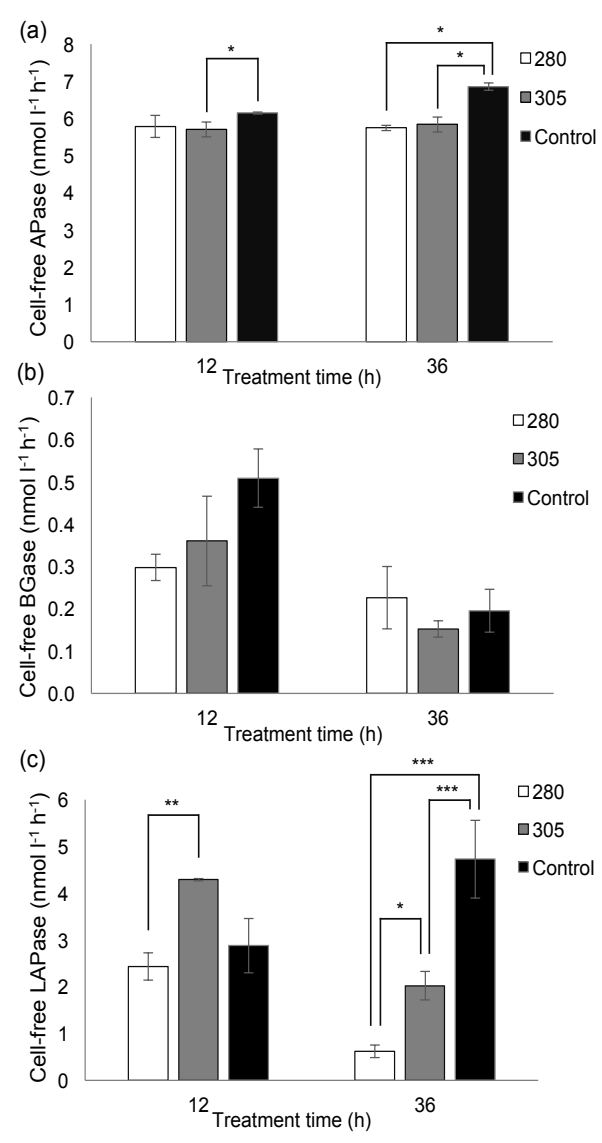

Figure 1. Results from UVR experiments showing the mean ( \pm SE) cell-free extracellular enzyme activity for alkaline phosphatase (a), beta-glucosidase (b), and leucine aminopeptidase (c), under a high dose $(280 \mathrm{~nm}$ and above) and a low dose ( $305 \mathrm{~nm}$ and above) in comparison to dark controls. Asterisks above bars represent individual significant effects between treatments in post hoc Tukey test $\left(*<0.05, * *<0.01\right.$, and $\left.{ }^{* * *}<0.001\right)(N=3)$.

\subsection{Statistical analyses}

In all analyses, parametric assumptions were first checked using the Shapiro-Wilk test for normality and the Levene's test for equal variance. Where appropriate, data were logtransformed to meet normality assumptions prior to analysis. Both experiments use a two-way analysis of variance (ANOVA) with an interaction term, with post hoc Tukey HSD tests run to assess the individual significant effects between treatments. All analyses were run in the R software environment ( $\mathrm{R}$ development core team, Austria).
Table 1. Total, cell-free, and proportion of cell-free relative to total extracellular enzymatic activity (EEA) in situ for the seawater collected for the UVR and temperature experiments at the time of sampling.

\begin{tabular}{lrrr}
\hline & $\begin{array}{r}\text { Total } \\
\left(\mathrm{nmol} \mathrm{L}^{-1} \mathrm{~h}^{-1}\right)\end{array}$ & $\begin{array}{r}\text { Cell-free } \\
\left(\mathrm{nmol} \mathrm{L}^{-1} \mathrm{~h}^{-1}\right)\end{array}$ & $\begin{array}{r}\% \text { cell-free } \\
(\%)\end{array}$ \\
\hline UVR experiment & & & \\
APase & 75.4 & 70.3 & 93.3 \\
BGase & 2.3 & 2.2 & 96.7 \\
LAPase & 35.4 & 7.5 & 21.1 \\
& & & \\
\hline Temperature experiment & & \\
APase & 121.9 & 121.8 & 99.9 \\
BGase & 3.2 & 2.7 & 85.8 \\
LAPase & 33.1 & 9.9 & 30.0 \\
\hline
\end{tabular}

\section{Results and discussion}

\subsection{UVR experiments revealed photodegradation of cell-free enzymatic activities}

The proportions of cell-free EEA in the seawater at the time of sampling were 93.3, 96.7, and $21.1 \%$ for APase, BGase, and LAPase, respectively (Table 1). Overall, UVR significantly decreased cell-free APase when compared to dark controls $\left(p<0.001, F_{2,12}=15.85\right.$, two-way ANOVA) (Fig. 1a). Individual significant effects between treatments in APase were seen as a significant decrease in activity in the low-dose treatment relative to the dark control at $12 \mathrm{~h}$ $(p<0.05$, Tukey HSD), and between the dark control and both the high and low-dose treatments at the $36 \mathrm{~h}$ sampling point $(p<0.05$, Tukey HSD). BGase cell-free activity was not significantly affected by UVR $\left(p=0.53, F_{2,12}=0.67\right.$, two-way ANOVA). UVR had a significant overall effect on LAPase, decreasing the cell-free activity when compared to dark controls $\left(p<0.01, F_{2,12}=40.994\right.$, two-way ANOVA) (Fig. 1c). Individual significant effects were seen in LAPase, showing a significant decrease in activity between the low and high dose at $12 \mathrm{~h}(p<0.01$, Tukey HSD) and showing a gradual decrease from high to low dose at $36 \mathrm{~h}(p<0.05$, Tukey HSD), and dark control to both low and high dose $(p<0.001$, Tukey HSD). Changes observed in the controls of all the enzymes from 12 to $36 \mathrm{~h}$ were not statistically significant ( $p>0.05$, Tukey HSD).

Apart from the possibility that UVR treatments may have influenced the composition of the seawater substrate itself, these experiments revealed a significant reduction in cell-free EEA for both APase and LAPase in response to UVR, consistent with the predicted photodegradation, which was not evident for BGase. This was the first time that UVR has been demonstrated to reduce cell-free enzymatic activities at environmentally relevant intensities. The only previous study (Steen and Arnosti, 2011) did show a reduction in the cell- 
free EEA of APase and LAPase but only at artificially high UVR intensities where UV-B was 5-10 times more intense from artificial lamps in the lab than outdoors. Interestingly, they could not show significant UVR effects on BGase at any treatment level, which is consistent with the present study.

Both APase and LAPase showed the strongest effect from UVR at the $36 \mathrm{~h}$ sampling point, suggesting a UV-B dosedependent response. LAPase also showed a gradual decrease in the effect between the low and high UVR treatments, which suggests the increase in UV-B irradiances also enhanced the degree of photodegradation. UV-B has been demonstrated to be a highly active part of the spectrum for degrading DNA in general (Sinha and Häder, 2002; Dahms and Lee, 2010), which is not only included in cells but is also an abundant component of the dissolved (extracellular) seawater fraction (Paul et al., 1987; Paul and David, 1989). Specific effects of UV-B on total extracellular enzymatic activities have been previously reported (Herndl et al., 1993; Santos et al., 2012; Demers, 2001; Müller-Niklas et al., 1995). However, it is important to distinguish these previous studies from the cell-free enzyme experiments performed here. Those previous studies tested the response of the entire microbial community, for total EEA, based on the assumption that UVR affects the organism (source of enzymes) directly. What is shown in this study is that UVR affects cell-free enzymes exclusively without the need to impact the source organism. The effects of UVR were different among the enzymes assessed, which may be of importance as some enzymes could be more impacted by UVR than others. For example, in this study, APase and LAPase were more affected by UVR than BGase, which could change the spectrum of extracellular enzyme activity in the surface of the ocean. The resulting higher BGase relative to APase or LAPase could potentially condition macromolecular DOC composition by hydrolysing relatively less proteins than carbohydrates in response to UV. In turn, it is conceivable that any change in the enzyme spectrum due to variability in UVR light could cause a loss of productivity (e.g. due to a decrease in the inorganic $\mathrm{P}$ made available through APase activities), as the nutrients made available by extracellular enzymes may not be in suitable ratios for the effective growth of microbes (Arnosti et al., 2014; Häder et al., 2007).

\subsection{Temperature experiments revealed enhanced catalytic activity of cell-free enzymes}

The proportion of cell-free EEA in the original seawater at the time of sampling was 99.9, 85.8, and 30.0\% for APase, BGase, and LAPase, respectively (Table 1). Temperature significantly increased cell-free APase at the high temperature of $15^{\circ} \mathrm{C}$ when compared to the ambient control of $10^{\circ} \mathrm{C}\left(p<0.01, F_{2,24}=34.63\right.$, two-way ANOVA) (Fig. 2a). APase activity was significantly increased, after $6 \mathrm{~h}$, in the high relative to the low temperature ( $p<0.001$, Tukey HSD) and after $12 \mathrm{~h}$ between low and high temperature $(p<0.001$,
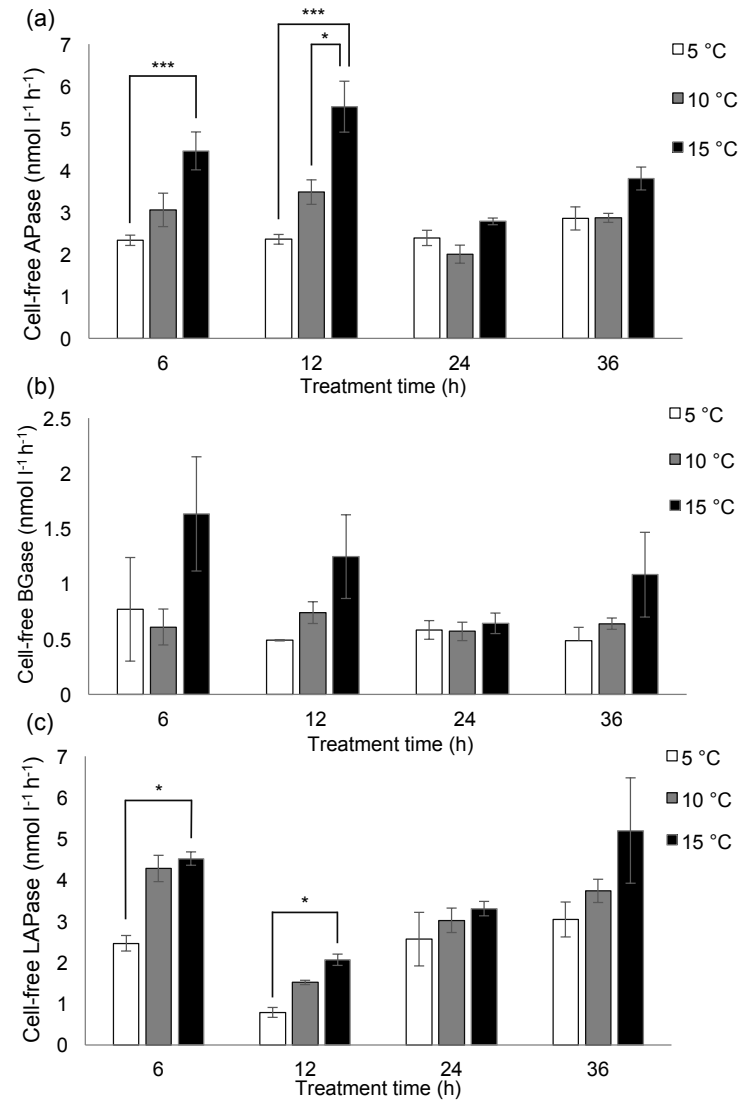

Figure 2. Results from temperature modification experiments showing the mean $( \pm$ SE) cell-free extracellular enzyme activity for alkaline phosphatase (a), beta-glucosidase (b), and leucine aminopeptidase $(\mathbf{c})$, under high $\left(15^{\circ} \mathrm{C}\right)$ and low temperature $\left(5^{\circ} \mathrm{C}\right)$ treatments in comparison to ambient controls $\left(10^{\circ} \mathrm{C}\right)$. Asterisks above bars represent individual significant effects between treatments in post hoc Tukey test $\left({ }^{*}<0.05,{ }^{* *}<0.01\right.$, and $\left.{ }^{* * *}<0.001\right)$ $(N=3)$.

Tukey HSD), and control and high-treatments $(p<0.05$, Tukey HSD). Cell-free BGase showed a similar pattern of increased activity in response to higher temperature but it was not significant (Fig. 2b). This lack of significant differences in cell-free BGase in response to temperature could be due to a relatively high variability in EEA among the high-temperature $\left(15^{\circ} \mathrm{C}\right)$ treatments. LAPase significantly decreased in the low-temperature treatment $\left(5^{\circ} \mathrm{C}\right)$, relative to the ambient control $\left(p<0.01, F_{2,24}=19.84\right.$, two-way ANOVA) (Fig. 2c). LAPase cell-free activity significantly increased between the low and high-temperature treatments at the $6 \mathrm{~h}$ and $12 \mathrm{~h}$ time points ( $p<0.05$, Tukey HSD). The temperature effect was dependent on time, finding significant effects after 6 and $12 \mathrm{~h}$, but not later for any of the studied enzymes.

The relationship found between temperature and cell-free enzyme activity is consistent with the general pattern of increased catalytic activity of enzymes in relation to temper- 
ature (Daniel and Danson, 2013). The positive relationship between temperature and the activity of cell-free enzymes observed in this study is contrary to the negative relationship between temperature and the proportion of cell-free relative to total EEA measured in a seasonal field study in the Baltic Sea (Baltar et al., 2016). However, it is important to take into consideration the fact that the study by Baltar et al. (2016) took place over a much longer timescale (1.5 years) and included the whole microbial community, whereas in this study different factors were teased apart by focusing only on the cell-free enzymes. This is supported by Baltar et al. (2016), where the proportion of cell-free relative to total EEA was significantly negatively correlated to prokaryotic heterotrophic production, suggesting that the low temperature preserves the constitutive activity of the cellfree enzymes (better than warm temperature) due to a reduction in the metabolism of heterotrophic microbes that would reduce the consumption/degradation of dissolved enzymes. The exclusion of heterotrophic microbes from our samples precluded this effect (i.e. heterotrophic degradation/consumption of free enzymes) of temperature from occurring and allowed us to tease apart the effect directly on the cell-free enzymatic activities. This also highlights the importance of scale when dealing with microbial oceanographic processes.

\section{Conclusions}

Overall, temperature and UVR were both demonstrated as potential control mechanisms for the activity of marine cellfree enzymes, providing a baseline for future research. This is the first report revealing the effects of photodegradation of cell-free enzymes at environmentally relevant levels of UVR and the effects of enhanced temperature on the catalytic activity of marine cell-free enzymes. Environmentally relevant UVR had a significant photodegradative effect that might be enzyme-specific (affecting APase and LAPase but not BGase) with the potential to alter not only the rates of cell-free EEA but also the spectrum of enzyme expression in the seawater. Alteration of the cell-free EEA spectrum from UVR variability could have ecological and biogeochemical implications like the conditioning of macromolecular DOM (i.e. affecting DOM composition by hydrolysing some DOM compounds more relative to others) and the change of the elemental ratio of some nutrients (e.g. affecting the availability of inorganic $\mathrm{P}$ due to a change in APase activity), with implications for productivity and nutrient cycling. Additionally, given the spatially and temporally variable UVR light regime (i.e. the $150 \%$ increase in UV-B in polar regions during springtime ozone depletion; Smith et al., 1992) and the documented anthropogenic changes in ocean temperature (Chen et al., 2007), it is probable that the activity of cell-free enzymes and their contribution to organic matter remineralization might be affected in the future, if not already.
Data availability. Experiment data are available on ResearchGate.net: https://doi.org/10.13140/RG.2.2.14690.02248.

Competing interests. The authors declare that they have no conflict of interest.

Acknowledgements. We would like to thank the team of technicians out at Portobello Marine Laboratory, most notably Linda Groenewegen and Reuben Pooley. This research was supported by a University of Otago research grant and a Rutherford Discovery Fellowship (Royal Society of New Zealand) to Federico Baltar. We would like to acknowledge the support and insightful comments of the reviewers, which clearly helped improve the overall merit of the manuscript.

Edited by: Gerhard Herndl

Reviewed by: two anonymous referees

\section{References}

Alderkamp, A. C., van Rijssel, M., and Bolhuis, H.: Characterization of marine bacteria and the activity of their enzyme systems involved in degradation of the algal storage glucan laminarin, FEMS Microbiol. Ecol., 59, 108-117, https://doi.org/10.1111/j.1574-6941.2006.00219.x, 2007.

Allison, S. D., Chao, Y., Farrara, J. D., Hatosy, S., and Martiny, A.: Fine-scale temporal variation in marine extracellular enzymes of coastal southern California, Front. Microbio., 3, 1-10, https://doi.org/10.3389/fmicb.2012.00301, 2012.

Amon, R. M. W. and Benner, R.: Bacterial utilization of different size classes of dissolved organic matter, Limnol. Oceanogr., 41, 41-51, https://doi.org/10.4319/lo.1996.41.1.0041, 1996.

Arnosti, C.: Microbial Extracellular Enzymes and the Marine Carbon Cycle, Annu. Rev. Mar. Sci., 3, 401-425, 2011.

Arnosti, C., Bell, C., Moorhead, D., Sinsabaugh, R., Steen, A., Stromberger, M., Wallenstein, M., and Weintraub, M.: Extracellular enzymes in terrestrial, freshwater, and marine environments: perspectives on system variability and common research needs, Biogeochemistry, 117, 5-21, https://doi.org/10.1007/s10533-013-9906-5, 2014.

Azam, F. and Cho, B.: Bacterial utilization of organic matter in the sea, Symposia of the Society for General Microbiology, Cambridge, in: Ecology of microbial communities, Cambridge University Press, Cambridge, 261-281, 1987.

Azam, F., Fenchel, T., Field, J., Gray, J., Meyer-Reil, L., and Thingstad, F.: The Ecological Role of Water-Column Microbes in the Sea, Mar. Ecol. Prog. Ser., 10, 257-263, https://doi.org/10.3354/meps010257, 1983.

Baltar, F., Arístegui, J., Gasol, J. M., Sintes, E., van Aken, H. M., and Herndl, G. J.: High dissolved extracellular enzymatic activity in the deep Central Atlantic Ocean, Aquat. Microb. Ecol., 58, 287-302, https://doi.org/10.3354/ame01377, 2010.

Baltar, F., Arístegui, J., Gasol, J., Yokokawa, T., and Herndl, G.: Bacterial Versus Archaeal Origin of Extracellular Enzymatic Activity in the Northeast Atlantic Deep Waters, Microb. Ecol., 65, 277-288, https://doi.org/10.1007/s00248-012-0126-7, 2013. 
Baltar, F., Legrand, C., and Pinhassi, J.: Cell-free extracellular enzymatic activity is linked to seasonal temperature changes: a case study in the Baltic Sea, Biogeosciences, 13, 2815-2821, https://doi.org/10.5194/bg-13-2815-2016, 2016.

Benner, R. and Amon, R. M. W.: The Size-Reactivity Continuum of Major Bioelements in the Ocean, Annu. Rev. Mar. Sci., 7, 185205, 2015.

Bochdansky, A. B., Puskaric, S., and Herndl, G.: Influence of zooplankton grazing on free dissolved enzymes in the sea, Mar. Ecol. Prog. Ser., 121, 53-63, https://doi.org/10.3354/meps121053, 1995.

Chen, Z., Marquis, M., Averyt, K. B., Tignor, M., and Miller, H.: Climate change 2007: the physical science basis. Contribution of Working Group I to the Fourth Assessment Report of the Intergovernmental Panel on Climate Change, Cambridge, Cambridge University, 2007.

Chróst, R. and Rai, H.: Ectoenzyme activity and bacterial secondary production in nutrient-impoverished and nutrientenriched freshwater mesocosms, Microb. Ecol., 25, 131-150, https://doi.org/10.1007/BF00177191, 1993.

Dahms, H.-U. and Lee, J.-S.: UV radiation in marine ectotherms: Molecular effects and responses, Aquat. Toxicol., 97, 3-14, https://doi.org/10.1016/j.aquatox.2009.12.002, 2010.

Daniel, R. M. and Danson, M. J.: A new understanding of how temperature affects the catalytic activity of enzymes, Trends Biochem. Sci., 35, 584-591, https://doi.org/10.1016/j.tibs.2010.05.001, 2010.

Daniel, R. M. and Danson, M. J.: Temperature and the catalytic activity of enzymes: A fresh understanding, 587, 2738-1743, 2013.

Demers, S.: The Responses of a Natural Bacterioplankton Community to Different Levels of Ultraviolet-B Radiation: A Food Web Perspective, Microb. Ecol., 41, 56-68, 2001.

Duhamel, S., Dyhrman, S. T., and Karl, D. M.: Alkaline phosphatase activity and regulation in the North Pacific Subtropical Gyre, Limnol. Oceanogr., 55, 1414-1425, https://doi.org/10.4319/lo.2010.55.3.1414, 2010.

Grove, S. and Probert, P. K.: Sediment macrobenthos of upper Otago Harbour, New Zealand, New Zeal. J. Mar. Fresh., 33, 469480, https://doi.org/10.1080/00288330.1999.9516892, 1999.

Häder, D. P., Kumar, H. D., Smith, R. C., and Worrest, R. C.: Effects of solar UV radiation on aquatic ecosystems and interactions with climate change, Photoch. Photobio. Sci., 6, 267-285, https://doi.org/10.1039/b700020k, 2007.

Heath, R. A.: Stability of some New Zealand coastal inlets, New Zeal. J. Mar. Fresh., 9, 449-457, https://doi.org/10.1080/00288330.1975.9515580, 1975.

Herndl, G. J., Müller-Niklas, G., and Frick, J.: Major role of ultraviolet-B in controlling bacterioplankton growth in the surface layer of the ocean, Nature, 361, 717-719, 1993.

Hoppe, H. G.: Significance of exoenzymatic activities in the ecology of brackish water: measurements by means of methylumbelliferyl-substrates, Mar. Ecol. Prog. Ser., 11, 299308, https://doi.org/10.3354/meps011299, 1983.

Hoppe, H.-G.: Microbial extracellular enzyme activity: a new key parameter in aquatic ecology, in: Microbial enzymes in aquatic environments, Springer, 60-83, 1991.

Hoppe, H. G., Arnosti, C., Burns, R. G., and Dick, R. P.: Ecological significance of bacterial enzymes in the marine environment, edited by: Rijksuniversiteit, G., 73-97, 2002.
Kamer, M. and Rassoulzadegan, F.: Extracellular enzyme activity: Indications for high short-term variability in a coastal marine ecosystem, Microb. Ecol., 30, 143-156, https://doi.org/10.1007/BF00172570, 1995.

Kim, C., Nishimura, Y., and Nagata, T.: High potential activity of alkaline phosphatase in the benthic nepheloid layer of a large mesotrophic lake: implications for phosphorus regeneration in oxygenated hypolimnion, Aquat. Microb. Ecol., 49, 303-311, https://doi.org/10.3354/ame01137, 2007.

Lamare, M., Pecorino, D., Hardy, N., Liddy, M., Byrne, M., and Uthicke, S.: The thermal tolerance of crown-of-thorns (Acanthaster planci) embryos and bipinnaria larvae: implications for spatial and temporal variation in adult populations, Coral Reefs, 33, 207-219, https://doi.org/10.1007/s00338-013-1112-3, 2014.

Li, H., Veldhuis, M., and Post, A.: Alkaline phosphatase activities among planktonic communities in the northern Red Sea, Mar. Ecol. Prog. Ser., 173, 107-115, https://doi.org/10.3354/meps173107, 1998.

Müller-Niklas, G., Heissenberger, A., Puskaríc, S., and Herndl, G.: Ultraviolet-B radiation and bacterial metabolism in coastal waters, Aquat. Microb. Ecol., 9, 111-116, https://doi.org/10.3354/ame009111, 1995.

Paul, J. H. and David, A.W.: Production of extracellular nucleic acids by genetically altered bacteria in aquatic-environment microcosms, Escherichia coli, Pseudomonas aeroginosa, Pseudomonas cepacia, Bradyrhizobium japonicum, Appl. Environ. Microb., 55, 1865-1869, 1989.

Paul, J. H., Jeffrey, W. H., and DeFlaun, M. F.: Dynamics of extracellular DNA in the marine environment, Appl. Environ. Microb., 53, 170-179, 1987.

Rainer, S. F.: Soft-bottom benthic communities in Otago Harbour and Blueskin Bay, New Zealand, Blueskin Bay, New Zealand, Dept. of Scientific and Industrial Research, Wellington, 1981.

Rego, J. V., Billen, G., Fontigny, A., and Somville, M.: Free and attached proteolytic activity in water environments, Mar. Ecol. Prog. Ser, 21, 245-249, 1985.

Santos, A. L., Oliveira, V., Baptista, I. S., Henriques, I., Gomes, N. C. M., Almeida, A., Correia, A., and Cunha, A.: Effects of UV-B Radiation on the Structural and Physiological Diversity of Bacterioneuston and Bacterioplankton, Appl. Environ. Microb., 78, 517-535, 2012.

Sinha, R. P. and Häder, D.-P.: UV-induced DNA damage and repair: a review, Photoch. Photobio. Sci., 1, 225-236, 2002.

Smith, R. C., Prézelin, B. B., Baker, K. S., Bidigare, R. R., Boucher, N. P., Coley, T., Karentz, D., Macintyre, S., Matlick, H. A., Menzies, D., Ondrusek, M., Wan, Z., and Waters, K. J.: Ozone Depletion: Ultraviolet Radiation and Phytoplankton Biology in Antarctic Waters, Science, 255, 952-959, 1992.

Steen, A. D. and Arnosti, C.: Long lifetimes of $\beta$ glucosidase, leucine aminopeptidase, and phosphatase in Arctic seawater, Mar. Chem., 123, 127-132, https://doi.org/10.1016/j.marchem.2010.10.006, 2011.

Weiss, M. S., Abele, U., Weckesser, J., Welte, W., Schiltz, E., and Schulz, G. E.: Molecular Architecture and Electrostatic Properties of a Bacterial Porin, Science, 254, 1627-1630, 1991. 